\title{
Identification of two enrichment patterns of shale oil in the Upper Cretaceous Qingshankou Formation, Songliao Basin, NE China \\ XU Xingyou ${ }^{1}$, LIU Weibin ${ }^{1}$, BAI Jing ${ }^{1}$, LIU Chang ${ }^{1}$, CHEN Shan ${ }^{1}$ \\ ${ }^{1}$ Oil and Gas Survey, China Geological Survey, Beijing 100029 \\ (925932678@qq.com,ogslwb@126.com)
}

The first member of the Qingshankou formation $\left(\mathrm{K}_{2} \mathrm{qn}^{1}\right)$ in the southern Songliao Basin mainly developed deep lacustrine shale which is a realistic oil and gas replacement area with abundant pure shale oil resources[1]. Exploration and development of the semideep-deep lacustrine shale is very difficult because of its high clay mineral content and extremely low permeability $[2,3]$.

Analysis of shale mineral composition, organic geochemical parameters, major elements and microscopic characteristics found that there was an obvious lithology-geochemical interface forming two independent shale oil systems in $\mathrm{K}_{2} \mathrm{qn}^{1}$. The research shows that the shale could be classified into 2 lithofacies. The upper layer shale developed horizontal bedding, its average content of clay was $63.7 \%$, the content of TOC was $3 \% \sim 5 \%$, the organic matter was mainly type I, We define it as high-TOC microstratification argillaceous shale wich was formed in deep-water humid strongreducing environment. The upper layer shale had the highest total oil content with average of $S_{1}$ was $5 \mathrm{mg} / \mathrm{g}$, its proportion of mobile oil was $45 \%$. The bedding fractures were the mainly effective storage spaces; The lower layer shale developed sandy strata, its average content of clay was $45 \%$, the content of TOC was $2 \%$ $3.5 \%$, the organic matter was mainly type $\mathrm{I}$ and $\mathrm{II}_{1}$ We define it as moderate-high-TOC laminated diamictic shale which was formed in a semi-deep water damp reduction environmentand. The layer layer shale had the higher total oil content with average of $S_{1}$ was $3 \mathrm{mg} / \mathrm{g}$, its proportion of mobile oil was $53 \%$. The intergranular pores of sandy strata were the mainly effective storage spaces;

According to comprehensive research, We build enrichment patterns of shale oil, they were high-TOC microstratification shale and moderate-high-TOC laminated shale. Based on these models, The JYY1HF well was deployed in the southern Songliao Basin. The well has obtained high-yield industrial oil flow with 16.4 cubic meters per day. Crude oil analysis results showed that the biomarker parameters of the oil from JYY1HF well are consistent with upper and lower layer shale. Therefore, the effectiveness of the two enrichment patterns of shale oil were confirmed.

Exploration breakthrough was obtained benefiting from the application of this research. More importantly, The new exploration field of terrestrial shale oil in China will be opened up.

[1] LIU Bo et al. (2018) Petroleum Exploration and Development 45, 828-838. [2] ZHAO Xianzheng et al. (2019) Petroleum Exploration and Development 46, 1-10. [3] DU Jinhu et al. (2019) Chian Petroleum Exploration 24, 560-568. 